\title{
SPOTTED
}

\section{Spotted around the web: Melatonin trial, striatum activity, CNTNAP2 timing}

BY JILL ADAMS

2 JULY 2021 